neuro-fibromatosis and xeroderma pigmentosum, achlorhydria is typical. The racial data demonstrate a constitutional susceptibility to physical irritants, particularly radiation. The work of Roffo and Findlay calls for further research in this direction although the general facts are clear.

Dr. Blank concludes that the complexity of factors noted above will be found to prevail equally in most forms and types and sites of tumours. As the cases of cancer in which we can trace direct hereditary transmission are rare, admittedly they cannot provide a valid answer to the question of whether, or to what extent, an inherited susceptibility plays a part in the general incidence of malignancies. From disorders indicating a purely hereditary proneness to tumour formation, such as xeroderma pigmentosum or neuro-fibromatosis, must be differentiated many other types of tumour formation about which nothing yet is known of an inherited tendency as, for example, cancer of the lip, which according to Waaler seems to be distributed quite independently of any inherited disposition.

Much remains to be done before these problems can be solved, but our task will be lighter if we heed the lesson already taught, namely, that it is vain to ask, "Is cancer hereditary?" and that we must inquire separately for each organ, tissue and type of the disease, whether any hereditary factors, direct or indirect, are involved in a specific form of the malady.

Summarizing our present position meanwhile, we can say that enough evidence has been accumulated to warrant at least the following statements: (a) Cancer is not a unit disease, at least so far as its genetical behaviour is concerned. Tumours of different sites and types differ in their genetical behaviour. (b) Therefore it is unlikely that a heritable condition of 'cancer' exists as such. (c) There does exist a general inherited disposition, whether of susceptibility or refractoriness to tumour formation. (d) In certain individuals factors exist, most probably inherited quite independently of a general disposition, which govern the localization of the disease. This localization in turn seems to depend upon a favourable 'intermal environment' in certain tissues or organs. (e) If general susceptibility and inherited favourable internal environment are combined in an individual, these factors may be strong enough in themselves to lead to cancer formation in certain tissues. ( $f$ ) If general susceptibility is very marked in an individual, even relatively slight irritation by agents of many kinds may lead to cancer formation. (g) But quite apart from these heritable conditions, there exist purely external carcinogenic agents of various kinds, which are obviously strong enough to lead to cancer-formation in certain tissues, even in individuals in whom there is no inherited predisposition, or perhaps it is too weak to be detected by methods used at present in testing for hereditary traits.

The above is a picture of cancer research as seen by the genetically minded physician. The chief aim of the survey has been to show that the whole problem of heredity and cancer is a biological question of highly practical bearing. The writer endorses MacDowell when he says: "It is highly regrettable that outside the immediate circle of geneticists, there seems to be an impression that the gene is selfsufficient and is either dominant or recessive. Especially as applied to neoplasms, this misunderstanding has led to erroneous conclusions both on the part of hostile critics and ardent believers. Dominance is only a special case at the end of a continuous series of interrelations between pairs of genes. ... No gene can produce its effect without the cooperation of many other genes. . . . And genes and extrinsic conditions cooperate in all cases".

Anthony Feiling.

\section{POPULATION PROBLEMS IN BRITAIN}

GIR W. LANGDON-BROWN, addressing the $\checkmark$ British Social Hygiene Council on the relation of social biology to the population problem (Brit. Med. J., 766, Dec. 9, 1944), said that he regarded with grave suspicion the efforts of planners to dethrone the family and hand children over to the State. Some family life is unsatisfactory, but the majority is good. The birth-rate in Britain has fallen steadily since 1870 and, in the same period, the infant deathrate had decreased and expectation of life had lengthened. There is evidence that the fertility-rate decreases with improved chances of survival. The British Social Hygiene Council has estimated that one-tenth of all marriages in Britain remained childless, but not deliberately so. A study of 2,000 cases suggested that in 60 per cent there was a defect on the man's part. In general, the average male fecundity is much lower than was generally assumed.

Other factors operating against the family are increased rents and rates, which absorb much more than the one tenth of income allowed for these in the Victorian scheme of things. This means that money which should go for food is spent on housing, with alarming effects on infant mortality and family life. There is an increase in life in flats due to aggrega. tion of urban populations, and flats are unsuitable for children. A standard rate of family allowances would not be satisfactory. The effects of late marriages and the consequent celibacy forced on our younger people by social changes must be recognized and studied by social biologists.

These and allied problems are the subject of a booklet issued by the Tory Reform Committee entitled "Tomorrow's Children" (P. S. King and Staples, Ltd., 14 Great Smith Street, London, S.W.1, 1s. net). This pamphlet rejects the thesis that the world will get too full in the future, because efforts to raise the birth-rate cannot do more than arrest the decline and because the progress of invention and science is always enabling us to support far greater populations at a higher standard of living. The maintenance of these greater populations depends on the fathers and mothers of the next thirty years. The problem before us is whether there will be enough people to keep things going when our grandchildren are grown up. Immigration may affect this problem considerably. Before this War, 50,000 more persons a year were entering Britain than were leaving it. In the future, Britain may attract thousands of the peasant populations of eastern Europe, and we may then be glad to let them in, just as the Dominions and the United States were before the War of 1914-18. But at present we are faced with a progressive decline of the population. The apparently satisfactory conditions at present are due, not to a good birth-rate, but to a low deathrate, resulting from improvements in public health, which allow more old people to survive. The raising 
of the net reproduction-rate to 1 , instead of the existing rate of $0 \cdot 75$, which this pamphlet recommends as a practical policy, would tend to stabilize the population at about three-quarters of its present figure.

The trend towards a rapid decline of population affects not only Great Britain, but also Norway, Sweden, France, Belgium, Switzerland and Austria, where populations will decline at about the same rate as Britain's will. Other countries, including Ireland, Germany, Italy, Russia, Japan, China and India, will show an increase by 1970 .

Among the causes of the population decline the pamphlet discusses (1) the enormously higher standard of living, leisure and comfort; (2) the great increase in mobility, which often makes the home into a place to be left as often as possible; (3) the almost universal literacy and widened outlook, due to reading in the local libraries and daily papers and to the radio; (4) the wide availability of contraceptives, which tend to affect the birth-rate in the groups of higher income and education; and (5) profound changes in our conceptions about religion, duty and social behaviour.

In Britain there is no spiritual significance of parenthood comparable to that which exists in India and China. Education stresses the importance of the individual, so that the child tends to ask what it can get out of life, rather than what it can give.

Among the remedies proposed by the Tory Reform Committee is the creation of a domestic service, which would make housework an attractive career. It also suggests that positive action should be taken in Parliament to bring this whole problem of population and family life more frankly before the people, to remove economic barriers to early marriage and to make two, three or four children an economic possibility in all classes, instead of a severe liability as they are at present. The alternatives against which the young married couples of the next few years can protect us if we enable them to do so are, the Committee thinks, decay through a progressively declining population, or immigration from countries with growing populations, including those of the East.

G. LAPAGE.

\section{POLLEN ANALYSIS AND THE MUSEUMS}

$\mathrm{H}$ A. HYDE, of the National Museum of Wales, has published an informative article on the technique, history and applications of pollen analysis (Museums J., Dec. 1944).

The study of atmospheric pollens in England began in 1867 when Charles Blackley, a Manchester medical practitioner, exposed to the air micro-slides treated with an adhesive, and found that the days when the slides showed most pollen grains coincided with those on which his hay-fever patients suffered worst.

In 1941 a detailed day-to-day census was begun at Cardiff, and the results obtained during 1942 (see "Studies in Atmospheric Pollen. I. A daily census of pollens at Cardiff, 1942". By H. A. Hyde and Dr. D. A. Williams. New Phyt., 43, 49; 1944) showed that the effective pollen season lasted from early March until late September, and (as previously discovered in the United States) presented three phases characterized by the pollens of trees, grasses and other herbs respectively. The applications of pollen research are numerous. At Cardiff the work is maintained chiefly for the purpose of assisting medical allergists in making their diagnosis; but in addition because it is of value in the pollen analysis of peat, in experiments on the hybridization of plants, and in meteorological work concerned with the movement of air currents. Again, pollen analysis has been employed-notably in Central Europe-in the determination of the source of origin of honey, and the author suggests that in the future bee-keeping and other departments of horticulture are likely to benefit from similar research. In this connexion he directs attention to the fact that the kinds of pollen collected by certain species of bees are already being investig. ated under official auspices.

Geological or archæological correlations are probably the most widely known applications of pollen analysis, but the work so far carried out does not yet provide a complete and independent time-scele for dating archæological finds. It has, nevertheless, made possible the reconstruction of the forest history of England and Wales since the close of the last Ice Age, and the working out of a number of correlations with human culture periods.

At the end of his paper the author suggests that "(pending the establishment of an institute of palynology ?)" at least the national museums should carry out fundamental pollen research, and that the larger regional museums might consider undertaking certain aspects of the work. In support of the desirability of this, he points out that certain public authorities in the United States carry out daily analyses of atmospheric pollens, and he is of the opinion that it will not be long before similar observa. tions will be required in Great Britain. Collaboration between museums and public health authorities (both often under the same municipal authority) would, therefore, be of mutual advantage.

\section{FORTHCOMING EVENTS}

\author{
Saturday, April 21
}

SOCIRTY OF INSTRUMRNT ThCHNOLOGY (at the London School of Tropical Medicine, Keppel Street, Gower Street, London, W.C.1) at 11 a.m.

Association For ScIENTIFIo PHotograpHy (at Caxton Hall, Westminster, London, S.W.1), at 2.30 p.m.-Mr. E. Mackie: "A Consideration of the Requirements for Micrography and Cinemicrography Apparatus".

\section{Monday, April 23}

ROYal Socierty of ARTs (at John Adam Street, Adelphi, London, W.C.2), at 1.45 p.m. Sir Frank Smith, G.C.B., G.B.E., F.R.S. "Chemicals from Petroleum" (Cantor Lectures, 2).

ROYAL GEOGRAPHICAX SOCIETY (at Kensington Gore, South Kensington, London, S.W.7), at 5 p.m.- "Fnthronement of the Dalai Lama and Journeys in Bhutan" (Kodachrome Films by Sir Basil Gould, with Commentary by Colonel F. M. Bailey).

INSTITUTTON OF ELEOTRICAL ENGINEERS (at Savoy Place, Victoria Embankment, London, W.C.2), at 5.30 p.m.-Discussion of "Electrical

association of Austrian Engineers, Chemists and Scientific ASSOCIATION OF AUSTRIAN ENGINFERS, CHFMISTS AND SCIENTIFIC
WORKERS IN GREAT BRITAIN (PHARMICCEUTYOAI GROOP) (at the WORKRRS IN GREAT BRITAIN (PHARMACEUTYOAL GROOP) (at the
Austrian Centre, 69 Eton Avenue, Hampstead, London, N.W.3), at 7.30 p.m.- "Some Interesting Facts on Sex-determining Compounds" (based on work by Mr. R. Kuhn).

\section{Tuesday, April 24}

Shemrimid Mmtallumgical Assooration (at 198 West Street, Sheffield 1), at 6.30 p.m.-Dr. H. O'Neill: "The Signiflcance of the Mechanical Test Properties of Metals".

QUERRTT Mrcroscopical CuUB (at the Royal Society, Burlington House, Piccadilly, London, W.1), at 7.30 p.m.-Mr. A. C. G. Best "Celloidin Embedding and Sectioning".

\section{Wednesday, April 25}

SoOIETy OF CHRMical INDUSTRY (FOOD GROUP) (at the Chemical Society, Burlington House, Piccadilly, London, W.1), at 2.30 p.m.Annual General Meeting; Mr. A. N. Duckham: "Food Management and the Chemist".

SOCIRTY Of Chemical INDUSTRY (NEWOASTLE-UPON-TYNE ShOTION) (in the King's Hall, King's College, Newcastle-upon-Tyne), at 5 p.m. orial Lecture). 